\title{
CHILEAN EDUCATION POLICY BETWEEN THE STUDENT MOVEMENT OF 2011 AND REFORMIST DEBATES OF 2014 ${ }^{1}$
}

\author{
La politica educativa chilena entre el movimiento estudiantil del 2011 \\ $y$ los debates reformistas de 2014 \\ Sebastián Donoso Díaz*
}

\begin{abstract}
This text, having the characteristics of an essay, is contextualized in the political scene of the present day Chilean society which has left behind the ghosts of dictatorship. This society can debate critical questions regarding its social organization, essentially referring
\end{abstract}

\footnotetext{
${ }^{1}$ Project work of the National Fund for Scientific Research and Technology of Chile, No 1120041. Funding from PIA- Conicyt Basal Funds for Centers of Excellence Project BF0003 is gratefully acknowledged.
}

This paper was initially sent for review in Spanish, and it has been translated into English with the support of the Project FP150008, "Aumento y mejora del índice de impacto y de la internacionalización de la revista Universum por medio de la publicación de un mayor número de artículos en inglés." Fund for publication of Scientific Journals 2015, Scientific Information Program, Scientific and Technological Research National Commission (Conicyt), Chile.

Este artículo fue enviado a revisión inicialmente en español y ha sido traducido al inglés gracias al Proyecto FP150008, "Aumento y mejora del índice de impacto y de la internacionalización de la revista Universum por medio de la publicación de un mayor número de artículos en inglés". Fondo de Publicación de Revistas Científicas 2015, Programa de Información Científica, Comisión Nacional de Investigación Científica y Tecnológica (Conicyt), Chile.

* Instituto de Investigación y Desarrollo Educacional (IIDE), Universidad de Talca. Talca, Chile. Email:sdonoso@utalca.cl

Article received January 7, 2015. Accepted March 17, 2015. 
to the field of educational which has been from beginning of this millennium the critical subject of notable social movements. The debates are situated at a strategically important point: they refer to corrections to the market or, definitively, a shifting of the paradigm in the sector. Taking this into consideration, the key points in dispute are exposed and possible ways to follow up are here described.

Keywords: Public policy, Educational Policy, Social Movements, Social Change, new paradigms in public education.

\section{RESUMEN}

El texto, que tiene características de ensayo, se sitúa en el auspicioso escenario político de la sociedad chilena actual, que ha dejado atrás los fantasmas de la dictadura y puede, entonces, debatir cuestiones críticas de su organización social, esencialmente referidas al campo educacional, que ha sido desde inicios de este milenio el tema crítico de los movimientos sociales de mayor significación. En razón de ello, los debates se hayan en un punto estratégico: se habla de correcciones al mercado o, definitivamente, cambio de paradigma del sector. En este punto, se exponen las lógicas en disputa, sus puntos claves y los eventuales caminos a seguir.

Palabras clave: Política pública, política educativa, movimientos sociales, cambio social, nuevos paradigmas en educación pública.

\section{PRESENTATION}

Since 2006, educational issues have had an important and growing presence in Chilean politics, reflecting the debates of a society experiencing strong tensions in several key areas related to its future. Due to criticism of the effects of an educational market model implemented in 1981, generating drawdowns related to political design despite some corrections from a democratic process, a great deal of social dissatisfaction remains. The presidential campaign of 2013 and a shift in the political orientation of the government beginning in March of 2014, from right to left-center, has given some citizens hope of better times to come. However, the issue has deeper roots, namely: the dilemma of keeping with the market model or implementing transformations of magnitude, involving a change that would reshape the fundamental ways that Chilean society thinks and acts. The political debates on education have centered around this dilemma, highlighting the many nuances that have yet to be considered as well as specific examples to be analyzed in a comprehensive case study. 


\section{ADJUSTMENTS TO THE MARKET MODEL OR THE SEARCH FOR A NEW PARADIGM IN EDUCATION?}

Student movements in 2006 and 2011 are milestones and essential considerations for the future of educational policy and public education in Chile. These occurrences, their breadth and depth, are the subject of many texts, writings, research, etc., which aim to highlight their full importance. Although an analysis of the trajectory of key issues in educational policy could span back to the beginning of the new millennium, the social crisis of 2006 exemplifies clearly what Burton (2012) called the period of "limited representation." This period is characterized by the operation of the hegemonic paradigm without counterweight and the consequent weakness of social movements, which occurred in the post-dictatorship political model as "a complete match between the state of the government and the state of social relations" (Rancière, 1996: 129). Others defined this period as the unfinished transition to democracy and its effects (Garretón and Garretón, 2010).

The student and social movements of 2006 break what had been a situation of full agreement between influential social groups and the political/economic society, created as an institutional response from the Presidential Advisory Council for Quality Education, whose final document (2006) presents keys to understanding both the recent past (1980 onwards) as well as new insights on the issue. As stated by Corvalan (2013), the convergence of many of the "stories" about the educational problem: the centerstatist, the market, and the attempted synthesis of both, are embodied by the policies of the Concertación ${ }^{2}$. It is within the Advisory Council that education as an instrument of equality in unequal societies is discussed, including the State's responsibility to provide access to education and educational content, as well as changes or innovations such as the self-limitation of state action as provider, the transfer of powers to private actors and profit. Transformations of scale are also mentioned, namely the redefinition of the relationship between state and society regarding educational provision through the passing of institutions once based in the central State to the mechanisms of the market (Corvalan, 2013).

Thus 2006 is the "discussion stage" of national education policy (Burton, 2012), being the turning point that opens the door for the stage of "limited representation" (2007 to date). This is understood as the overt expression of tensions that were unrecognized and unresolved before being mentioned to the Council (2006), during the "democracy of the agreements" which neutralized these tensions and maintained political and social stability. These tensions, manifesting themselves with new vigor, divided political and social groups based on three primary areas

${ }^{2}$ Concertación de Partidos por la Democracia, political coalition of the center-left that presided over the administration of the State in the the first four post-dictatorship governments (1990 to 2010). 
of conflict: profit in education, (re)defining the role of the State, and selectivity/ segregation within the education system. The social movement of 2011 was largely sustained by factors related to free education (including tertiary).

The relevance attained by both social processes and their incremental impact on the political agenda to date has given us a glimpse of a massive transformation, which could reach paradigmatic proportions, as education -beginning in 2006- has become the unifying axis of the unfinished social process which has attracted greater public attention.

Social movements around education, as that of 2011, questioned "the market" as the great organizer of the educational system. However as one issue was cornered, another replaced it as the new articulator of social relations. The fact that in Chile education is considered a commodity to be distributed according to market rules is far more difficult to address than the initially anticipated problem. It was not enough to reduce the market to a network of relationships, because as a social phenomenon it is a maze of complex networks affected by various political, economic, religious and philosophical enclaves built over the course of three decades of hegemonic operation. This ideological/explanatory framework serves to protect -until nowagainst reformist attacks, including attempts made through the democratic process, at first more convincing and later less so $^{3}$.

Advancing critical positions in the market and the search for a new paradigm under which to organize and distribute education, the defendants of neoliberalism abandoned an open defense of the market as a guarantor of efficiency and freedom. They instead held on to the contrary - that the Chilean education system does not work as a market, seeing education as being recognized in the constitution as a right (Art. 19, No 10). That is to say that society (the State) provides education to those who are not able or willing to pay, which would be sufficient to demonstrate that it is not on the market.

Despite this reasoning being incorrect, it is currently politically unacceptable that one who can not afford to pay be left without an education. For certain within the market scheme they who aspire to a higher quality must pay for it. Each person can pay for the education they want, different "qualities of education" being traded openly in the market. Thus, paying a higher price for receiving a better education is what has been called to question, for which market advocates have no other answer than the one indicated.

Conservative groups, clinging to the slogan "public education is of poor quality," argue that the solution is not to change the system of educational provision,

\footnotetext{
${ }^{3}$ For example, in the first attempts were made in the 90s to change the "Ley Orgánica Constitucional de Enseñanza" (LOCE) implemented by the dictatorship to avoid changes in the sector. There was another at-tempt after the social movements of 2006 , where there was practically no political discussion.
} 
but to improve the quality of education that is offered for free. Fundamentalists do not acknowledge the ways in which "quality education" is traded in the market. The neoliberal argument ignores that by not having different qualities of education, the market would become meaningless. Making the market attractive to investors and families who choose to pay requires the establishment of a minimum quality provision for the poorest segment of society. In this context, the conservatives fail to respond to the questions of how reasonable and just an educational system that guarantees only a minimum, in which a student receives only the education that their family can afford to purchase in the market, can be. According to Sandel (2012), the dilemma has two aspects: whether or not criteria can be identified for the market to distribute education, and what these criteria consist of. This considering that Chile represents an extreme version of neoliberalism, in which the market is responsible for distributing virtually all types of goods.

In this context, following the demands of the social movements of 2006 and 2011 and their impacts on the political agenda, one might think with a degree of illusion that a significant and well articulated social change was coming in education. This change would ultimately involve a paradigmatic transformation of the Chilean state, based on a new relationship between itself and its citizens, replacing the aim of market-driven profit maximization with a supportive relationship. Thus changes are sought, but involved in the implemen-tation are technical, regulatory and financial elements to creating a public policy proposal that seeks to create a society with greater rights for all citizens.

In the meantime the conservative argument in this matter was evolving, unforeseen during the euphoric days of the social movement of 2011, and demonstrating that neoliberalism is far from its "extinction." Much of the libertarian slogans were done away with insofar as they served to maintain the market, however the complexity of "deconstructing" a market is much higher than constructing it. It is difficult to implement this transformation solely in education without considering other key sectors. In addition, the market requires only a few simple principles to operate while its replacement involves a more elaborate network in order to function, including greater political agreement on founding principles. Many of the slogans produced by the social movements in consideration were not sufficient to guide its implementation.

Finally, the neoliberal ideology has penetrated so powerfully throughout these years that there are people willing to defend the education market and demand "the right to pay for education," which ultimately becomes a "discrimination tax" that allows children of certain families to safely share with "equals" (Valenzuela, Bellei y de los Ríos, 2008; Bellei, 2013). It has been shown that in Chile, socioeconomic factors run parallel to the few differences in the contribution of subsidized private and public education (Drago y Paredes, 2011), and the low value added of schools 
(Treviño and Donoso, 2010). For this reason the discriminating price structure is emphasized, as the contribution from schools is low.

Despite the discussions, it is evident that a delegitimization of the market was not enough to cause its collapse. Many of the expected proponents of the market have come to its defense (secular and religious businessmen, politicians and leaders of the private sector) as well as the unexpected, namely some families of the "emerging middle class sectors," demanding their right to pay for education. Demanding the possibility of buying in the educational marketplace, claiming they do not have an interest in a system that ensures a higher quality free education, they have no confidence in the state or society: it is the great triumph of neoliberalism that each manages as they are able.

One criticism of the movements of 2006 and 2011 is that the model did not reach the degree of strength and coordination required to break the power networks built by neoliberalism. Its weakness as a social movement would have begun when demands for education were reduced ${ }^{4}$ (Oct. / Nov. 2011), betting in turn that they were "playing all reforms," which was not so, as has been demonstrated in the course of events of March 2014 and onwards. In this last period there are changes in language, inflection and content between the first announcement from the government and those that followed, each time increasingly attenuated, having more consensus with power groups and making less reference to the original slogans of the social movements 5 .

It has become clear that the thematic linking of parties with social movements was intended to make reforms to the model rather than to change it, integrating diverse social actors without first delineating the entirety of a social project. In this way the issue was reduced to one of the education sector only, and not of the social decision on how to distribute different goods considered to be public (Sandel, 2012). In this context, proreform advocates have been losing strength, clarity and dynamism. These aspects, together with the counterargument presented by conservatives to reduce the issue of public education to its limited scope and not that of the existence of the market as a whole, showed the legitimacy of the daily behavior and awareness of the people.

\footnotetext{
${ }^{4}$ It has been noted by specialists, without necessarily having an empirical basis that endorses it fully, that the new Chilean middle class can be explained and mobilized with two axes: consumption and education.

${ }^{5}$ An example is the purchase of private schools by the Treasury and the refusal to join the reforms on profit control. This matter was pressured by changes to the leasing system and finally a system of valuation as a way to repay borrowed resources in a period of 6 months.
} 


\section{LOGIC IN THE STRATEGY FOR CHANGE}

Understanding that the debate on strengthening public education involves defining the significance of the changes and determining relevant strategies and measures for its implementation. The case in analysis, however, does not follow this formula. Rather politics are mixed with the feasibility of certain changes, without having carried out a discussion on the core of the subject. If it seeks to reform the market, correcting the imbalances and shifting the paradigm of the state, it will involve important government decisions from within the New Majority (Nueva Mayoría). This in turn may call into question the paradigm shift and provoke another social upheaval.

Improving the market initially reduces tension between the ruling powers in various fields, while a paradigm shift certainly creates a greater degree of uncertainty. The first is a clear path to carry out corrective measures, with an emphasis on the public institution delving into the socioeconomic components of the population and its impact on educational services along with certain regulations for the private sector. The second is more profound, redefining education as a social right, which translates to "being a citizen" as sufficient reason for providing it. This is what market advocates do not accept as it literally signifies its disappearance. Under the umbrella of social rights, this is a public issue as everyone is entitled to the same privileges. A system ought to be organized to meet that goal based on the "richness of society" expressed in the financial resources capable of assigning such a task (Atria, 2014).

This public debate has not taken all nuances into consideration. The Government has promoted two strategic pathways which initially point to market corrections, but viewed closer may involve more than that. The first pathway is directed at the private sector that receives public funding, with some significant modifications to their actions; the second aims directly at strengthening the public.

\subsection{Proposals to reform "the market model" at the school level}

The focus in this area relates to the private sector that receives public funding, which in Chile makes up a large percentage of student enrollment. The debate is not whether or not the private sector should exist, nationalization being politically infeasible as well as not being the central problem, but centered rather around education being distributed under market rules. Therefore, what is targeted is to supplement currently lacking measures to regulate providers of education receiving public funds, considering the rights and duties of public education.

Nor is the discussion about the freedom of teaching and/or the private educational initiatives, as has been proposed by some advocates of the market 
model. The sense of freedom of education in Chile is that not all education is provided by the state. This does not mean that one may teach what they want under any standard. Freedom of education must consider educational projects from the civil society in their various expressions while maintaining a sense of consistency (Atria, 2014). This is not the current problem, and contributes to deviate attention away from the fact that education is organized in Chile under market criteria. What is sought by the proposed changes is a reformation of the Chilean education system, to one in which education is a right for all citizens and is no longer treated as a commodity.

Beyond the proposal developed by the current government, which speaks to changes rather than reform despite being named as one of the major reforms (MB Program, 2013), are the first legislative initiatives addressing citizenship in relation to the educational debate. Some themes approached in these initiatives include the role of the private sector, gratuitous education understood as a system of copay for families, and the end of the selection process of students as well as profit in the educational sector.

The principle of free education ${ }^{6}$ is closely associated with equal access and educational processes, and must be understood in terms of these objectives. In the case of Chile, gratuity is foundational to the vision of education as a social right and is a manner in which to achieve equality of opportunity and rights in the society. Replacing the copay system for families, less so for the entrepreneur who would be seeking those funds from the same State, is rather because it is no longer an efficient instrument for the selection of students, the reinforcement of discrimination and social exclusion (Valenzuela et al., 2008; Bellei, 2013). Secondly, the copayment system or "Financiamiento Compartido" has been an important instrument in the funding of private schools, which is why the proposal also involves its gradual elimination. It is also possible to generate positive externalities by reducing management costs of this system.

The debate has been extremely idealized as opposition groups have described opportunities as a persecution of freedom of education, which is not consistent with facts and circumstances. The business sector has responded to the initiative that the proposed measures do not represent a relevant financial issue, but for gratuity to be effective in this way, private institutions would be obligated to receive all students regardless of their vulnerability. This would create a decline in school performance in the medium term as well as a migration of students to other institutions, producing a "social mix" generate by non-selection. These factors

\footnotetext{
${ }^{6}$ Free being understood at the point of service, cost being paid under a budget from the State.

${ }^{7}$ Approved in 1993 by the first democratic government. It is defined as copayment, structured in sections, and involves a monthly fee for student families.
} 
would affect well-specified power groups who seek to prevent the elimination of copayment. In addition, it could also have negative impacts in the short term for the public sector, as copayment as acted as a barrier to non-migration for those who those wishing for that option yet are not able to pay, thus remaining in public education. Eliminating this obstacle could result in a migratory phenomenon in public education. For this reason, it is required to strengthen as well public education in the short term to reduce this unwanted effect.

As stated, the principle of free education is closely associated with equal access and educational processes, and for Chile are key issues as universal coverage is achieved with the indicated provisions - which does not imply equality in education ${ }^{8}$. Therefore it is a dimension that must be addressed, as if not implemented it would have a negative impact on the most vulnerable segment of the population.

Closely related to the above is student selection, as it has implications both for social segregation as well as that of profit for businesses with access to public resources 9 . Currently the General Education Law (LGE) prohibits the selection of students up until the 6th grade. It is well known that these restrictions have not prevented a significant number of private schools and some public schools from selecting students ${ }^{10}$. During the time that the Organic Law of Education (ESWL) was effective, from March of 1990 to August of 2009, this process was facilitated in private institutions while at the same time being prevented in public ones. This guaranteed the legitimacy of the selection made by private schools while reducing an eventual social conflict in the absence of such a rule. Many of the achieved results of subsidized private schools were due to the social capital of their students rather than the value added of the education they provide, a product of the migration of "less poor" students from the public system to subsidized private schools (Treviño y Donoso, 2010; Mizala y Torche, 2012).

The selection of students for copayment and/or meritocratic reasons, both correlated to socioeconomic factors, guarantees better educational results thanks to the effect of the "social cradle," which in Chile's case is decisive. For this reason, it is key for entrepreneurs to maintain it either overtly or covertly as operational criteria as it allows private institutions to charge higher tuition based on academic results. In this way they legitimize profits and increase both efficiency and quality of education services, though it is not ultimately generated by the institutions themselves (Atria, 2014; Donoso, 2013).

\footnotetext{
${ }^{8}$ See results of the national standardized test (SIMCE) as well as the international test (PISA) as evidence of processes/results.

${ }^{9}$ It is criticized that some companies and educational entrepreneurs profit with public resources, an issue that occurs in both secondary and tertiary education, although by law the latter is prohibited. ${ }^{10}$ Understood that selection takes place when there are more applicants than vacancies. The criticism focuses on the employment of meritocratic elements associated with socioeconomic factors.
} 
The third medium of intervention is the regulation of profit, a complex criterion to implement in a system characterized from its outset by deregulation. While some purposeful subsidies were achieved democratically, in recent years the private education system has grown quantitatively (a 15 to $53 \%$ increase in tuition and more than tripling its number of institutions), allowing significant resources to be managed by an important set of powerful companies (Carlini et al., 2013). Any initiative to regulate this matter involves entering into a very complex field, as demonstrated by debates held on the topic. The government's aim has been to impede these companies with purchases and leases based on figures out of the market, which have characterized profit in the Chilean system of higher education ${ }^{11}$. Establishing these criteria has created tensions between the government and some business groups.

The three subjects contained in the law that seeks a market correction are substantial issues and as such, to implement them in the terms discussed, will require time to take full effect. As noted, the plot of these measures, the interests at stake, the powers involved and the depth of their implications demonstrate a high degree of political complexity. It is also possible that with objective negotiations, it will finally be reduced to market correction and will fail to reach the depth necessary to affect change and create a link between the various measures ${ }^{12}$.

\subsection{On the paradigm shift in education from the State}

The possible paradigm shift in education from the State should be the cornerstone of the strategy for the public sector, however it is not at all evident that measures at this level are directly binding with that goal. This does not imply a judgment of their importance, as several of them are fundamental for a company of this magnitude.

As was noted, the strengthening of public education requires direct measures to support the sector, some urgent and others less so. These measures are also needed for the regulation and control of the subsidized private sector, otherwise the public institutions cannot effectively carry out their work due to the imbalance of rights and duties with private schools. Even though the situation may improve as some measures take effect, it is essential to implement larger changes, though more difficult to do so, in order to shift the paradigm. It is also necessary to assume that education has a relational dimension, therefore being substantive, and to understand that both sectors require this dimension operate effectively.

In this context a decisive, unavoidable, and even imperative step is to increase the financial resources allocated to the public sector in a direct and substantive manner.

\footnotetext{
${ }^{11}$ See www.ciperchile.cl for a report regarding profit in Chile's system of higher education.

${ }^{12}$ They are in fact proposals as three separate bills: one which regulates profit, another that eliminates the copay system, and a third that prevents the selection of students.
} 
What was laid out in the budgetary framework of 2014, defined by the Government of the right, allowed for only a few adjustments. However, it is essential to also think of new financing options which have more substantive rationales for education than the current system of subsidization based on student attendance ${ }^{13}$. These mechanisms need to be consistent with the meaning of education as a social right, such as with contributions adjusted to socioeconomic characteristics of the school population served as well as the educational objectives to be achieved (OCDE, 2004, Donoso, 2013).

In the second instance, it is necessary to provide public educational institutions integrated financial reforms, also referred to as a new architecture that meets the demands of "demunicipalization." These are demands that have been formulated from different points of view and resolve structural problems that require an intervention on that scale, which if not met call into question the future of the sector (Bellei et al., 2010; Ceppe, 2011; Elacqua et al., 2010; Eyzaguirre, 2012; García-Huidobro, 2010; Marcel y Raczynski, 2009, Martinic y Elacqua, 2010). This indespensible task is a challenge to realize in a country that is exceptionally centralized, and demands for its transformation a paradigmatic shift ${ }^{14}$.

These changes are also an opportunity to move decisively toward greater decentralization. For example, making decisions concerning the transfer of powers from the central Government to the regional Governments (Finot, 2007), generating more autonomous public institutions related to macro territories, providing them with corporate governance, technical capabilities and management, and the ability to implement and promote long-term public education projects with financing consistent with these goals (Marcel, 2012, Bertoglia et al, 2011, Mejía y Anastasio, 2008). This task, although indespensible, at the same time presents a challenge in an excessively centralist country. For this reason it is necessary to enable a paradigmatic transformation.

Thirdly, before any transformation takes place it is necessary to address several sub-stantive and urgent matters, namely: (i) the need to fundamentally transform the teacher training system in the country. Under the consideration of factors related to moving beyond socio-economic determinants in education, there is a transversal theme of the quality of teaching practices confirmed by a low added value. This indicates a strategic problem that if resolved, will have an impact felt only in the following decade and is therefore an urgent matter. As a matter of the State that is significant for various institutional leaders in the country, it requires a solid social agreement in an arena in

${ }^{13}$ A detailed review of the mechanisms of financing, their foundations and critical aspects is presented in Donoso, Sebastián (2013) The Right to Education in Chile: New Citizenship After the Neoliberal Twilight, edited by Bravo and Allende, Santiago, Chile. Chapter III. Financing policies and the right to education pp. 87-120.

${ }^{14}$ In September of 2014, a commission studied the proposals delivered to the Government which ranged in topic from the direct election of political authorities to greater sectoral autonomy. This route would begin in the year 2015, although relevant measures for education are proposed for 2018. 
which actors are currently barely able to identify the problem in its magnitude and outline its specifics, much less form viable proposals for solutions.

A second task, (ii) much more complex but equally important, is the design of a new teaching and directive career consistent with the new institutions of education to be created. This form should transcend the public sphere to also integrate the private sector receiving public grant money -in the style of other countries- but implies a political agreement with the business sector. Private entrepreneurs may not feel inclined to reforms at this level as they generally have a less demanding regiment for pay and employee contracts than does the private sector. The advantages of this matter are considerable for the stability and development of teachers, and indeed positively impact the quality of the teaching and management of the educational establishment. For this reason the discussion should commence promptly, knowing full well the difficulty of the processes and implications at various levels.

At a third level of transformation, structural measures consistent with the proposed paradigm should be undertaken on several fronts. Politically, it is very important that a change of this magnitude is a legitimate response to the problem of its origin. For this reason politicians should sustain themselves in a wide social agreement for education, committed to strengthening the democratic State for its citizens, toward a new role in response to the demands of social rights.

In the area of governance, the Chilean State is underequipped to efficiently meet the demands of its population. The existing educational institutions, more fragmented than in the previous decade, demonstrate modified rather than systemic design solutions. At this level, weaknesses due to limited size and power are exposed.

Similarly, institutions and state management processes should conform to the redesign of public education at the subnational level. These processes should be articulated in a way that does not promote further fragmentation and bureaucracy. Though greater technical and financial autonomy would serve to reduce that possibility, in the decision-making process are complex political issues in a highly centralized Chilean State (Eaton, 2012).

To eliminate the education market will require significant influence to regulate supply and demand at the regional level. These influences are not currently available due to the "dogma" of a deregulated marketplace. Expanding them, including the tertiary system under analysis and given its extensive population coverage (more than $40 \%$ of the population in the respective age group), will involve analyzing some areas with an apparent oversupply of professionals.

It is important to understand that introducing greater public regulation in different areas and on different levels does not directly imply a lesser market. As has been observed by some private officials, it is required to transform the base of the model, incorporating a set of factors that if not present, will result in the public ending up inevitably "controlled" by the private sector as has happened in recent years. 
The principle changes represented by the new paradigm are to constitutionally consider education as a social right and a responsibility of the State, along with other social rights. Consistently, the State is obliged to provide provisions and mitigate concerns with a determined standard of quality. Changing the system of financing compulsory education, in both subsidized public and private provisions, will be unavoidable. The issue will involve more resources, costs being adjusted to reflect the standards of operation, the size of the institution, the social and cultural capital of its population, and the location and range of targets to be reached. This requires new principles on which to sustain financing and accordingly, to install mechanisms and instruments consistent with the social right to education.

The design should be supported by the new subnational institutions of public education, which must replace the current and failed system, with fluidity between financing and these institutions. Any imbalance in the dialogue, as the Chilean experience has shown, could have consequences in the medium and long term. Similarly both components, new subnational institutions and new forms of financing, are required to articulate a fragmented system of national education. All new institutions involve a redesign of this system, at least from the Ministry, and are conducive to system-wide modernization (Núnez y Weinstein, 2010). This matter also considers decentralization policies and the functions of the central State with subnational entities such as the provision of administrative and technical capacities. The issue to be resolved is the degree to which decentralization is feasible to imple-ment and how exactly to progress forward.

From this same perspective, a basic institutional democracy is required to manage education in its medium and long-term tasks. It is necessary to implement validation practices for citizenship as well as strategies at both subnational and national levels, with their respective legal support and taking into account this new paradigm in its entirety.

\section{FINAL REFLECTION}

Education is a central issue for Chilean society, where diverse perspectives come together with different emphases on individual, social, and socio-economic development. One of its key missions, as stated iteratively in critical moments, is its contribution to governance as it requires major changes in order to respond to needs. It speaks to a relationship between an integrated democratic process and the technical expertise needed to implement efficient solutions. There are major challenges in the field of decentralized decision-making and management in a society that has no practice in this regard. To make such a shift requires that citizens understand the sense of the State, representative democracy, and their duties and 
rights within the framework. For this a major structural change in both the system of education and the consciousness of the public is needed.

\section{REFERENCES}

Atria, Fernando. La mala educación. Ideas que inspiran al movimiento estudiantil en Chile. 1a edición. Santiago, Chile: Catalonia - CIPER, 2012.

Atria, Fernando. Derechos sociales y educación: Un nuevo paradigma de lo público. Santiago de Chile: LOM, 2014.

Ball, Stephen. "Privatising education, privatising education policy, privatising educational research: Network governance and the 'competition state", Journal of Education Policy 24 /1 (2009): 83-99. DOI: 10, 1080/2680930802419474.

Bellei, Cristián, Cabalin, Cristián y Orellana, Víctor. “The 2011 Chilean student movement against neoliberal educational policies", Studies in Higher Education 39 / 3 (2013): 426-440.

Bellei, Cristián.” El estudio de la segregación socioeconómica y académica de la ecuación chilena", Estudios Pedagógicos XXXIX / 1 (2014): 325-345.

Bellei, Cristián, Contreras, Daniel y Valenzuela, Juan Pablo. "Fortalecer la Educación Pública: Un desafío de interés nacional”. En Cristián Bellei, Daniel Contreras y Juan Pablo Valenzuela (Eds.), Ecos de la revolución pingüina. Avances, debates y silencios de la reforma educacional. Santiago, Chile: Universidad de Chile UNICEF - Pehuén Editors S. A., (2010): 225-256.

Bertoglia, Luis, RaczynskI, Dagmar y Valderrama, Consuelo. 20 Años de politica educativa descentralizada con efectos tardios en calidad y equidad de la educación ¿Ausencia de enfoque territorial? Santiago, Chile: RIMISP, 2011.

Beyer, Harald y Velasco, Carolina. "Una educación pública más efectiva ¿los árboles no dejan ver el bosque?” En Cristián Bellei, Daniel Contreras y Juan Pablo Valenzuela (Eds.), Ecos de la revolución pingüina. Avances, debates y silencios de la reforma educacional. Santiago, Chile: Universidad de Chile - UNICEF, (2010): 183-224.

Burton, Guy. "Hegemony and Frustration: Education Policy Making in Chile under the Concertacion 1990-2010”, Latin American Perspectives 39 / 4 (2012): 34-52. 
Castro, Moyra. "Descentralización educacional en Chile: Itinerario sin territorio", Innovar. Revista de Ciencias Administrativas y Sociales 22 / 43 (2012): 7792. Bogotá: Universidad Nacional de Colombia.

CEPPE. Qué hacer con la educación municipal?Centro de Estudios de Politicas y Prácticas en Educación. Santiago, Chile: Pontificia Universidad Católica, 2011.

Corbalán, Francisca, Ligüeño, Sebastián y González, Juan. "Identificación de la Propiedad y Dinámica de la Oferta Educativa Particular Subvencionada de la Región Metropolitana”, Revista MAD 20 (mayo de 2009): 110-127. Disponible en: http//www.revistamad.uchile.cl/20/corbalan_05.pdf

Corvalán, J. La narrativa educacional chilena y su proceso de transformación reciente: Un análisis sociológico-histórico, Folios, segunda época (2013): 63-81.

Donoso, Sebastián. El derecho a la educación en Chile. Nueva ciudadanía tras el ocaso neoliberal. Santiago, Chile: Bravo y Allende Editores, 2013.

Drago, José Luis y Paredes, Ricardo. "La brecha de Calidad en la Educación Chilena”, Revista Cepal 104 (agosto de 2011): 167-180.

Eaton, Kent. "The State of the State In Latin America: Challenges, Challengers, Responses and Deficits", Revista de Ciencia Politica 32 / 3 (2012): 643-657.

Elacqua, Gregory, Martínez, Matías y Aninat, Cristóbal. `¿Cómo fortalecer la educación municipal? Capacidad y responsabilidad política”. En Sergio Martinic y Gregory Elacqua (Eds.), ¿Fin del Ciclo? Cambio en la Gobernanza del Sistema Educativo (pp. 101-130). Santiago de Chile: Unesco - Pontificia Universidad Católica, (2010): 101-129.

Eyzaguirre, Sylvia. "Fortalecimiento de la educación escolar pública: ¿Desmunicipalización?”, Puntos de Referencia 340 (2012). Disponible en: http://www.cepchile.cl/dms/archivo_4958_3061/pder340_SEyzaguirre. pdf.

Finot, Iván. "Los procesos de descentralización en América latina”, Investigaciones Regionales 10 (2007): 175-205. 
García-Huidobro, Juan. "Para hacer pública la educación pública". En Sergio Martinic y Gregory Elacqua (Eds.), ¿Fin de ciclo? Cambios en la gobernanza del sistema educativo. Santiago, Chile: Unesco - PUC, (2010): 81-100.

Garretón, Manuel Antonio y Garretón, Roberto. "La Transición Incompleta en Chile: La realidad tras los ranking internacionales", Revista de Ciencia Politica (Santiago de Chile) 30 (2010): 115-148.

Gobierno de Chile. Orientaciones y Prioridades Presupuestarias 2015. Ministerio de Hacienda. Dirección de Presupuesto. Santiago, Chile. (octubre de 2014).

González, Pablo. "Estructura Institucional, recursos y gestión en el sistema escolar chileno". En Cristián Cox (Ed.), Políticas Educacionales en el Cambio de Siglo. La reforma del sistema escolar en Chile. Santiago, Chile: Editorial Universitaria, (2003): 597-660.

Jofré, Gerardo. "Subvenciones en educación", Estudios Públicos 32 (1988): 31-55.

Le Grand, Julian. "Quasi-market and social policy”, The economic journal 101 / 408 (septiembre de 1991): 1256-1267.

Marcel, Mario. Modelos alternativos de descentralización y la experiencia chilena. Santiago, Chile: Cieplan, 2012.

Marcel, Mario y Raczynski, Dagmar. La asignatura pendiente. Claves para la revalidación de la educación pública de gestión local en Chile. Santiago, Chile: Colección CIEPLAN - Uqbar editors, 2009.

Martinic, Sergio y Elacqua, Gregory (Eds.). ¿Fin del ciclo? Cambio en la gobernanza del sistema educativo. Santiago, Chile: Unesco - PUC, 2010.

MINEDUC. Ministerio de Educación, datos de matrícula, 2003. Consultado en: http: //www.mineduc.cl.

Mejía, Consuelo y Anastasio, Oracio. Descentralización en América Latina. Estudio de Caso. DOC. No 30/08. Instituto de Estudios Fiscales. España, 2008.

Mizala, Alejandra y Torche, Florencia. "Bringing the schools back in: The stratification of educational achievement in the Chilean voucher system", International Journal of Educational Development 32 (2012): 132-144. 
Núñez, Iván y Weinstein, José. “Chile: ¿Una reforma educacional sin reforma del Ministerio? (1990 -2007)”. En Inés Aguerrondo (Coord.), Institucionalidad de los Ministerios de Educación. Los procesos de reforma Educativa de Argentina y Chile de los años 90. París: IIEP, (2010): 95-220.

OCDE. Chile. Revisión de Politicas Nacionales de Educación. Organización para la Cooperación y el Desarrollo Económico. París: OCDE, 2004.

OCDE. Panorama de la Educación. Organización para la Cooperación y el Desarrollo Económico. Madrid: OCDE - Santillana, 2013.

OCDE. Education at a Glance 2014. Organización para la Cooperación y el Desarrollo Económico. París: OCDE, 2014.

Picazo, María Inés. Las politicas escolares de la concertación durante la transición democrática. Santiago, Chile: Ediciones Universidad Diego Portales, 2013.

PISA. Análisis de los resultados de las Pruebas PISA - 2009. Santiago, Chile: Ministerio de Educación, 2009.

Programa MB (2014 - 2018) Programa de Gobierno de Michelle Bachelet. Santiago, Chile (octubre de 2013): 23-29.

Rancière, Jacques. El desacuerdo. Politica y Filosofía. Buenos Aires: Nueva Visión, 1996.

Roemer, John. Variantes de la igualdad de oportunidades. Revista Fractal, No 16 enero-marzo. (2000) Año IV volumen V. Disponible en: http://www. mxfractal.org/F16roeme.html

Sandel, Michel. Lo que el dinero no puede comprar: Los limites morales del mercado. Barcelona: Random House Mondadori, 2012.

Treviño, Ernesto y Donoso, Francisca. Agrupación de escuelas para intervenciones de politica: Análisis del caso chileno. Santiago, Chile: Universidad Diego Portales, Facultad de Educación, 2010.

Valenzuela, Juan Pablo, Bellei, Cristián y de Los Ríos, Danae. Evolución de la segregación socioeconómica de los estudiantes chilenos y su relación con el financiamiento compartido. Santiago, Chile: FONIDE - CIAE, 2008. 